\title{
Communicative, information and education environment of modern museum
}

\author{
Konstantin Y. Milovanov ${ }^{1,{ }^{*}}$, and Ekaterina E. Nikitina ${ }^{1}$ \\ ${ }^{1}$ ISED RAE, Laboratory of history of pedagogics and education, 105062, Moscow, Russia
}

\begin{abstract}
The potential of the modern museum and ways of its use in modern educational practice are considered in the article. Great importance is given to the interpretation of the museum space in the context of its communicative and creative opportunities. The museum knowledge is perceived as the integration of many scientific directions: training, information, education, culture and history, art criticism through which a personality becomes familiar with new knowledge and moral values.
\end{abstract}

Museum pedagogics as a branch of pedagogical knowledge operates with categories and concepts of applied cultural science, museology and pedagogics, such as "museum education", "museum teacher", "museum communications", "museum educational space", etc. Being incorporated in a conceptual and terminological outline of museum pedagogics these definitions often receive other semantic loading or get new, uncharacteristic for them shades of meaning earlier.

Development of theoretical constructs of museum pedagogics has led to the integration of traditional (excursion) and innovative (interactive) forms of the internalization of museum values. Methodological fundamentals of museum pedagogics have organically united the fundamental principles of education philosophy, theoretical pedagogics and the specifics of museum and education multisubject space. Museum pedagogics as a scientific discipline is organized by taking into account features of the development of the modern museum in which the unique subject and spatial environment is created on the basis of public cultural dialogue and interactions with objects of art.

The close attention of the scientists who pursued museum pedagogics has been focused on the dialogue as the most important form of museum communication for more than a century, however only modern electronic technologies have allowed to deepen dialogical communication, to make it the most important component of the process of museum space development [1]. With the sharp growth of the amount of visual information within the last century it is difficult for museums to draw public's attention to the unhurried examination of exhibits in the quiet and beautiful halls. Museum pedagogics is pedagogics of the open cultural and educational environment because it isn't confined to the museum walls and most effectively proves out in the conditions of the cooperation between the school and the museum, the unification of cultural and educational institutions, the creation of expediently organized cultural and pedagogical space. Museum establishments, which are carrying out the function of preserving and saving cultural environment, "set as a purpose of their activity not only to store, collect and study various artifacts, but also to influence society, awakening school children's and students' creative interests, stimulating their self-determination and selfrealization" [2].

Now museums interact with education institutions (preschool institutions, schools, secondary professional education institutions and higher education institutions), quite often special divisions on work with children and the youth are created in museums (It should be noted that in practice these museum structures do not always look for contact with education institutions, but organize their work directly with children and parents). Education institutions cooperate with museums: by the principle of territorial arrangement; proceeding from the leading terms of reference of a museum establishment (centralized visits of field-specific museums are organized); on the basis of a head-teacher and pupils' common interests. Many schools and pre-school education institutions organize their own museums, however, in most cases education museum work is based on the interaction with museum establishments.

The organization of interactive exhibitions and introduction of the advanced museum and pedagogical technologies imply active acquaintance with cultural and education space of the museum. At the present stage museums "face a problem of searching for new means and methods of public awareness building, education and pedagogic activity, new forms of work with different groups of the population, and first of all children and the

Corresponding author: milkonst82@mail.ru 
youth, on forming national consciousness, national selfidentification, creating conditions for understanding the role and the place of culture in the human community" [3].

The museum becomes a means of subject and environmental information enrichment. Modern museum pedagogics aimed at the development of the creative potential of a personality is realized through the cultural and educational activity of museums in the special forms. The subject matter aspect of the interaction of the museum with the personality becomes an innovation of modern education and reveals itself through the creation of education programs, the system of methodological knowhow as a means of providing qualitatively new information to visitors. The organization of events, directed to activating creative abilities of pupils, is not less important for the development of the museum activities for children. In this context school-children's creative work acts as a basis for integrating pupils' education experience and the museum potential.

Reflecting social transformations in the society and culture, museums also undergo changes in their structure, contents and activity. It is quite obvious that museum activity gains the increasing socio-cultural importance, the pedagogical role of museums in preserving and interpreting cultural heritage, in difficult processes of social adaptation, cultural identification, as well as in teaching and education process considerably increases. The modern museum actually becomes a real center of education and information technologies in the field of culture and creative innovations. Creating virtual space of an operating museum today is not uncommon. In the near future it will be possible to speak with confidence about the museum-education information environment. On the website of a museum, during a videoconference in a students' audience or in a school class it will be possible to see museum halls, the most interesting exhibits in the virtual space. A guide's narration in the museum or on an excursion route through historical places (in the on-line mode or in record) can become part of a lesson or part of an excursion in the museum.

In the course of interaction with museum collections a visitor acquires "the originality of art development in the course of self-education: the internalization of culturally set norms of communication with art, the increase of interest in classical art, the increase of the level understanding the fine arts" [4]. At the present level of development of museum pedagogics museums actively become the most effective and open information area in the conditions of informal and further education. Now special significance is attached to museum and pedagogical technologies for the development of various strategies of interacting with visitors. Scientific, methodological and educational activities of the museum are a basic basis of social and cultural adaptation. The museum with the help of its social and cultural activity raises the value of art as factor of spiritual education of our society, considerably expanding its influence in the educational environment.

The perception of a museum subject is impossible without a communicative contact. The famous art critic, professor B.A. Stolyarov, defines pedagogical interaction of the museum with an education system as "communication which is a pedagogical phenomenon where the relation between subjects assumes a spiritual component" [5]. In this context the pedagogical contact of a viewer with a museum subject represents a certain psychological and pedagogical system which is bases on the following model.

The first block represents a viewer's perception of works of art. At this stage there is a formation of artistic images in the consciousness of a personality through the penetration of an artist's individual plan into a viewer's space.

The second block is the understanding of a plot component of a work in the context of an author's art world and in the context of time. At this stage a viewer compares, draws analogies between the image of a picture and different events of the real time and that historical era in which this masterpiece was created.

The third block represents revealing an ideological, key plan of a work of art. A viewer finds for himself "new knowledge", finds the answer to the questions: "What is this work created for?, What semantic loading does it have? How did the artist manage to put his feeling of the world in his creative activity?"

The fourth block consists in the acquisition by a person of some spiritual experience, and also in the enrichment by the new valuable knowledge necessary for the development of "a new format" personality in the conditions of the modern society.

The existing model of the pedagogical interaction of a museum with its audience is very important for the development of creative and cultural potential, as communication in the museum space is also a dialogue, coauthorship with the author of a work. At this stage a teacher's experience which ensures schoolchildren's successful adaptation to the world of art acquires special importance. A dialogue as a form of communication gets a big priority in the contents of modern training packages for elementary school. For this purpose the authors of programs and teaching manuals offer training of younger school students in various types of creative works with obligatory application of reproductions of pictures of famous artists. An excursion serves as a form of communicative interaction of the museum and audience in the course of which the formation of common cultural competences and values can act as an additional element of pupils' acquaintance with the world of art. Museum design of communicative contact is built according to the following tasks:

1. formulating the relevance of valuable knowledge in the form of the subject and the purpose of an excursion (a project or an exhibition);

2. defining audience composition; 
3. forming the main stages of the perception of cultural and historical contents (For example, participants can be organizers of a scientific search);

4. preparing and implementing a museum scenario. In this way participants of museum excursion are offered to revise the new knowledge of cultural and historical contents gained during the excursion doing certain tasks, exercises, answering questions;

5. ensuring a creative dialogue between the author (artist), the host of the project or excursion and participants in the form of a conversation or a dialogue on a certain subject;

6. developing new communicative structures. This direction is realized through attracting nonprofessionals to the museum environment - for example, providing the right to members of other professional communities to present objects of their culture in the exposition of a museum.

The system of the listed above tasks opens new horizons of the museum communication. The museum of today is not only a place for visiting, but also a system of communication between different members of our society. This fact is very important as in the course of such interaction there is an assimilation of new knowledge, cultural and historical experience and moral and esthetic values [6].

The communication in the Internet space organized by a museum teacher or a school teacher allows to discuss widely objects of art, to involve the increasing amount of people in the discussion, to prepare for the art perception of originals in the museum or to discuss the results of a visit to the museum, forming artistic taste. Certainly, Internet communication can't replace a visit to the museum, examining original works; nevertheless it is very important that by means of electronic resources it is at least to some extent possible for a wide range of people in the most remote corners of the country and the world to get acquainted with the incalculable richness of large museums.

The transformation of museum communication types, the use of electronic means and the intensification of interpersonal communication, on the one hand, allow the museum "to survive" in the modern information space. On the other hand, it gives a chance to support continuous contact with real or virtual visitors of the museum, deepening their readiness and depth of the perception of cultural heritage, helping them to master culture language, symbols and meanings of artistic images. The modern socio-cultural situation around the world raises a direct question: museums either become a place of cultural and historical intergenerational dialogue, or storages of hardly required old things, and in the latter case, their destiny, and, maybe, destinies of the country and the world, will become deplorable. For this reason the role of museum pedagogics which reveals itself in the activity of museums or in the creation of school museums is extremely big. A museum teacher by all possible means, among which electronic means are the most expressive and often available, forms in a person a visitor of a museum, attracts visitors to the museum.

Practically all available forms of work with audience can be carried out in the electronic mode, and besides information technologies have generated new forms which are actively entering the life of museums. Such tasks of the cultural and educational activity of museums as educational, informative, training, communicative, entertaining can successfully and effectively be solved by using electronic resources. It is important to note that interactive forms of museum work are actively adopted by children and teenagers owing to their modernity, an opportunity to make an independent choice based on personal interests. The factor of motivation and involvement into the museum and cultural environment in the interesting to the young developing formats is very important.

The newest period of developing cultural and education space of the modern museum demands that museum expositions should be mobile, nonlinear and non-standard. Virtually the museum space is also formed out of the museums in new forms. So, the federal TV channel "Kultura" shows magnificent models of the display of collections of masterpieces, carrying out lectures in interiors of the monuments of cultural heritage, etc. The All-Russian society of protecting historical and cultural monuments (ARSPHCM) by request of the Department of cultural heritage of the Government of Moscow realizes "Exit to the City" project recreating cultural and education space in non-museum buildings and in city streets. All this is carried out with wide use of electronic means of communication. It is out of the question that with application of electronic means a new life of museums, the growth of interest in our cultural heritage among youths have begun, and we are waiting for miraculous discoveries and opportunities.

Complex, daily interaction of museums and education institutions is possible only with innovative approaches of museum pedagogics defining today its new place in the society and solving its main task - to direct children and youths to genuine masterpieces, monuments of cultural heritage. Each large museum possesses its own system of work with visitors of different age groups caused by the profile of a museum and the developed traditional forms of promoting museum knowledge. The museum and educational environment has to promote the social organization and adaptation of various social layers and age groups, and also by means of active training of social activity with the help of museum pedagogics to help them to find their place in the modern society, to realize themselves as patriots and citizens. The fact is indisputable that "museums take an important part in the process of forming pupils' patriotism, friendliness to other nations and civic consciousness" [7].

Using up-to-date pedagogical technologies, the museum can and has to solve education and training tasks, 
encouraging a person's involvement in active coauthorship. The socio-cultural sphere of the modern museum "gains individual, personal character which basis is the internalization of the cultural space of the museum through emotional perception and intellectual comprehension" [8]. The training and education functionality which has the amplest opportunities in overcoming the existing monopoly of the verbalism of the traditional school was strongly attached in scientific and methodical literature to the museum. The national education system assumes a certain formalization of cognitive activity and is based on the principles of modern didactics of the post-industrial society. However, education at the same time is the major sphere of "social life which provides the formation, storage and transferring of the fundamental principles providing unity and viability of a social organism" [9].

The museum is a social institution which supplements and deepens educational activity of education institutions, leads the museum teacher, the guide and the visitor into the uniform field of the intersubject relations and actively realizes the cultural, training and education potential. The cultural heritage which is saved up centuries in the museums possesses a characteristic property, it has to interact with modern society, as only in this case it will generate spiritual powers, enrich socio-cultural processes, promote the emerging of new incentives and directions of socially significant activity.

The museum fund of Russia is the richest, genuinely "gold" stock of our country, which is not only the subject to devaluation, but also is inexhaustible, as well as our national culture. The museum space plays the most important culture-forming role of the guarantor of the continuity of cultural, education and training processes in the modern society.

\section{References}

1. S.V.Ivanova, O.V. Ivanova, K.Yu. Milovanov, and E.E. Nikitina, Muzeinaya pedagogika kak oblast' pedagogicheskoi nauki (FGNU ITIP RAO, Moskva, 2012) [In Rus]

2. S.A. Pakhomova, Novye tsennosti obrazovaniya: kul'turosoobraznaya shkola: nauchno-metodicheskii sbornik, ( «Narodnoe obrazovanie», Moscow, 2002) [In Rus]

3. N.V. Burov, Pedagogicheskaya kul'turologiya muzeinoi deyatel'nosti (Kontsert, SPb, 2009) [In Rus]

4. V.S. Sobkin, A.V. Fedotova, Trudy po sotsiologii obrazovaniya, (Institut sotsiologii obrazovaniya RAO, 2012) [In Rus]

5. B.A. Stolyarov, Pedagogicheskie aspekty obrazovatel'noi deyatel'nosti muzeya (SPb, 2013) [In Rus]

6. K.Yu. Milovanov, Otechestvennaya i zarubezhnaya pedagogika, 1 (2013) [In Rus]

7. Z.Z. Gelmutdinova, R.Sh. Raymanov, Patrioticheskoe vospitanie uchashchikhsya $v$ protsesse deyatel'nosti shkol'nogo muzeya (Mezhvuzovskii tsentr vospitaniya kul'tury mezhnatsional'nogo obshcheniya, Moscow, 2007) [In Rus]

8. E.N. Mastenitsa, Muzeinoe prostranstvo kak kul'turologicheskaya kategoriya (EIDOS, SPb, 2010) [In Rus]

9. M.V. Boguslavskii, T.N. Boguslavskaya, V.M. Lobzarov, K.Yu. Milovanov, and K.E. Sumnitel'nyi, Preemstvennost' $i$ novatorstvo $v$ razvitii osnovnykh napravlenii $v$ otechestvennoi pedagogicheskoi nauke (konets XIX-XX vv.) (FGNU ITIP RAO, Moscow, 2012) [In Rus] 